\title{
ORGANISATIONAL COMMITMENT AS INTERVENING VARIABLE ON THE EFFECT OF PSYCHOLOGICAL EMPOWERMENT ON ORGANISATIONAL CITIZENSHIP BEHAVIOUR
}

\author{
Heuk Yosef Fernando Coopertino \\ STIE Malangkucecwara, Malang, Indonesia \\ nandocoopertino@gmail.com \\ Aryani Dwi Nita \\ STIE Malangkucecwara, Malang, Indonesia \\ dwinita@stie-mce.ac.id

\section{Munfaqiroh Siti} \\ STIE Malangkucecwara, Malang, Indonesia \\ riroh@stie-mce.ac.id
}

\begin{abstract}
The purpose of this research is to determine the causal relationship between organisational citizenship behaviour, organisational commitment, and psychological empowerment at the employees of Hartono Electronics Company Malang. The sample taken from the population is 89 people. Model testing was carried out by using Partial Least Square (PLS) analysis. Hypotheses testing used path analysis, $r$ test, and t-test. The results proved that the relationship between organisational commitment, and psychological empowerment organisational citizenship behaviour towards employees had a positive significant effect. The Organisational Commitment is the intervening variable in the relationship between Psychological Empowerment on Organisational Citizenship Behaviour (OCB). The adjusted $\mathrm{R}$ square is $53.5 \%$ means that OCB is explained by organisational variables namely Psychological Empowerment and Organisational Commitment, and the rest may support by other variables.
\end{abstract}

Keywords: behaviour, citizenship, commitment, organizational, psychological.

DOI: https://doi.org/10.24818/beman/2021.11.2-03

\section{INTRODUCTION}

Human resource is one of the significant resources in an organisation because human always has an active role and dominant in any organisation activities. The success of employees in finishing their duties determines the success of an organisation in reaching the goals. Organisations believe that to achieve excellence, optimizing the potential of the individual employee performance is a must. It is because the 
individual performance affects the team performance and ultimately affects the overall performance. The behavior that the organisation demands in the present-day is not only in-role actions that mean doing related works in the job description. It is also about the extra-role in doing the duties outside the job description without expecting praise, material, and non-material rewards. The extra-role action is also called organisational citizenship behavior (OCB). OCB is a voluntary action by individuals, although it is not part of their duties as part of the organisation; but, on the initiative to give the best to the organisation.

Eisenberger (2001) says that organisational behavior develops in line with how much the attention to the welfare and the awarding of employees' contribution. The perception of organisational support (perceived organisational support) is where the employees feel confident that their workplace values their contributions and cares about the welfare and positively relayed to their work achievement.

Psychological empowerment increases the employee service, their willpower to finish the duties, and encourage problem-solving, and trying to improve the overall performance. Psychological empowerment is a set of statements needed for each individual to have a sense of control in their work performance. Psychological empowerment is the level of empowerment cognition felt by individuals (Mangundjaya \& Ratnaningsih, 2017).

Organisational commitment is an encouragement from individuals to make an effort to support the success of the organisation following the goals and prioritize the interests of the organisation rather than personal interests. Organisational commitment is required as an indicator of employee performance. Employees with a high commitment can be expected to show optimal performances, and someone who joins an organisation at a company is required to commit.

Intense competition among companies, demands for excellent service and agile employees, requires qualified and nimble human resources. Without qualified and loyal employees, this will cause a company to be in problems such as the difficulty of a company in managing the organization to achieve their goal, poor service quality which in turn causes consumers to switch to looking for other stores. Many research in human resources topics have examined factors affect $\mathrm{OCB}$, however very little studies employed organisation commitment as an intervening variable.

A research on manufacturing firm in Kenya done by Kariuki and Kiambati (2017), Lavelle et al. (2009), generated that organisational performance is affected by psychological or employee empowerment, the association between employee empowerment and organisation performance is mediated by organisational commitment, but not mediated by OCB. Furthermore, according to Taştan and Serlinkan (2013), Bhatnagar and Sandhu (2005), psychological empowerment had a positive effect on OCB at the IT manager in India. The relationship between psychological empowerment and organisational commitment is positive and significant has been asserted by Seibert, Wang, and Courtright (2011). Nevertheless, Suriadnyana (2020) argued that employee empowerment did not affect organisation commitment. The 
correlation between employee empowerment on organisation commitment may weak when there is a conflict between employee and supervisor at secondary school teachers in The Netherlands (Janssen, 2004). Previous results examined the effect of psychological empowerment and organisational commitment on OCB, however literature has emerged that offers contradictory findings about factors affected OCB. Therefore, the aims of this study are to shine new light on the debates through an examination of the influence of Psychological Empowerment on Organisational Commitment and Organisational Citizenship Behavior, and to test the effect of Psychological Empowerment on Organisational Citizenship Behavior through Organisational Commitment as intervening variable. The findings from this study will give several contributions to the literature, namely, to enrich the theory of human resources and give evidence of fundamental concept of organization behavior and factors influence OCB.

\section{THEORIES, LITERATURE REVIEW AND HYPOTHESES}

\subsection{The influence of Psychological Empowerment on Organisation Commitment}

The definition of employee empowerment (psychological empowerment), according to Wibisono and Widjaja (2014), is to enable and provide employees the opportunities in making plans, implementing plans, and controlling the work plans that become their responsibility. It infers that employee empowerment or psychological empowerment is a situation when employees feel, they can understand the meaning of work, believe in their abilities to complete work, have full control in determining work methods, and can influence work operation strategies. In addition, "managing employees with attractive training, coaching, and motivation methods are aimed to make employees will not feel forced to carry out their duties and responsibilities properly (Afin Murtie, 2012).

Rebentrost et.al (2014) exhibited that there is a significant positive relationship between employee empowerment and employee commitment to the organization commitment. Psychological empowerment is a significant predictor of organisational commitment. Out of the five dimensions of psychological empowerment, three of them are the significant predictors of commitment. In addition, a significant positive relationship between employee empowerment and organisational commitment revealed by Wadhwa \& Verghese (2015). The study held by Yani et.al (2016) exhibited that psychological empowerment has a significant positive effect on organisational commitment. It also has a significant-good influence on job satisfaction. Psychological empowerment has a significant positive effect on organisational commitment through job satisfaction. Research conducted by Joo and Shim (2010) has shown that there is a positive influence between psychological empowerment on organizational commitment. Therefore the Hypothesis 1 (H1): Presumed that Psychological Empowerment has a positive effect on Organisational Commitment 


\subsection{The influence of Psychological Empowerment on Organisational Citizenship Behavior}

Organizational Citizenship Behavior (OCB) is a special type of work behavior that is defined as individual behavior that benefits the organization, which is not directly or explicitly recognized by a formal reward system. OCB behavior is thought to have an important impact on the effectiveness and efficiency of team and organizational work, thus contributing to the overall productivity of the organization. Organisational citizenship behaviors conclude loyalty, deviant behavior, and participation affect employee intentions in leaving the organisation. Organ (2006) defines Organizational Citizenship Behavior (OCB) as the behavior of a person who has the freedom to choose, not solely due to the official reward system, and this is done to improve the effective functioning of the organization. To clarify OCB behavior, Organ (2006) divides it into five main dimensions, namely: Altruism, Conscientiousness, Sportmanship, Courtesy, Civic Virtue. Employees who have a freedom to determine how they behave and complete the jobs related to the forming aspects of Organizational Citizenship Behavior, namely conscientiousness, which is behavior shown by trying to exceed what is expected by the company.

Putra (2017) stated that psychological empowerment is a source of internal employee motivation, which can increase one's personal motivation and stimulate a more active on Organisational Citizenship Behavior. Furthermore, Putri \& Ratnaningsih (2018) mentioned that psychological empowerment has a direct effect on Organizational Citizenship Behavior. Corroborating with previous results, Triatmanto (2017) explained that psychological empowerment has a significant relationship with Organizational Citizenship Behavior. Therefore, Hypothesis 2 presumed that Psychological Empowerment has a positive effect on Organisational Citizenship Behavior.

\subsection{The influence of Organisational Commitment on Organisational Citizenship Behavior}

As stated by Christine (2014), "organisational commitment is that employees or individuals are more productive so that in the end it will be more profitable for the organisation. Commitment to an organisation does not only mean more than passive loyalty but involving a very high desire of employees in the organisation to serve and fight for the organisation to its full potential." Prihantoro (2012) utters that "interpreting organisational commitment is an attitude that shows employee loyalty and is the continuance of how a person or individual in an organisation expresses their concern for the success of an organisation and the good and progress of the organisation." Based on those definitions, organisational commitment is including the elements of loyalty to the company, involvement in the work performed, and identification of the company's values and goals. Thus, there is a definition of commitment from several experts aforementioned that emphasize the process of individual employees in identifying themselves of values, rules, and objectives of the organisation. 
Potgieter, et.al (2015) explained that the perception of employees towards their leader empowerment behaviours include maintaining employee accountability, making independent decisions, and developing human resources. In addition, Robbins and Judge (2015) which states that Organizational Citizenship Behavior can arise from various factors in the organization, including due to high organizational commitment from employees.

Meanwhile, Pradhiptya (2013) found that organizational commitment had a positive and significant effect on Organizational Citizenship Behavior. This means that the higher the organizational commitment, the higher the Organizational Citizenship Behavior. Prameswari \& Suwandana's research (2017) states that the factors that drive employee Organizational Citizenship Behavior are influenced by several motives, namely commitment to the organization where there is a desire to participate well in the organization and are proud to be part of the organization. Thus, there is a possibility that $O C$ influences $\mathrm{OCB}$, so the hypothesis $3(\mathrm{H} 3)$ becomes Organisational Commitment has a positive effect on Organisational Citizenship Behavior.

\subsection{The influence of Psychological Empowerment on Organisational Citizenship Behavior through Organisation Commitment}

Luthans (2011) says, "Organisational Citizenship Behavior as a discretionary behavior, is inexplicitly recognized by the normal requirements of work, but aggregately can improve the effective function of the organisation." According to Kreitner and Kinichi (2005), OCB behavior can be reflected by two acts namely first, employees who behave cooperatively in their work can create a positive impression among their colleagues. Second, the more employees who act cooperatively in completing works, it contributes to building organisational effectiveness and is not directly related to their reward system. OCB behavior is a voluntary action by individuals, although it is not part of their duties as part of the organisation; but, on the initiative to give the best to the organisation." Based on those definitions, the writer defines that organisational citizenship behavior is an act that is not part of the formal rules of the organisation, voluntarily action by employee, and if it is completed, will have a good influence on the organisation.

If it is suspected that PE effect on OCB through OC. Thus, the hypothesis $4(\mathrm{H} 4)$ is Presumed that Psychological Empowerment affect Organisational Citizenship Behavior through Organisational Commitment.

\section{RESEARCH METHODS}

\subsection{Type of Research, and Population}

This study is a quantitative research with the type of causality research. According to Sugiyono (2011), a causal relationship is a relationship that involves cause and effect. The researcher used this type of 
research because of the presence of compatibility with the problem that is interrelated between cause and effect. The scope of this research is the employees of Hartono Electronic in Malang. The population in this study is 102 employees who work at the Hartono Electronics Company in Malang, however after distributing the questionnaires, only 89 sheets returned.

\subsection{Variables, Operational, and Measurement}

Psychological Empowerment (X1)

In this study, psychological empowerment is an independent variable of psychological empowerment felt by the individuals (Spreitzer, 2008). Psychological empowerment consists of four dimensions, i.e., meaning, competence, self-determination, and impact. Significance is defined as an individual's experience when the individual believes that the job given is substantial and results in responsibility. Competence refers to a feeling of individual ability to complete a job. Self-determination is the freedom of individuals to choose how to get work done in the way they choose. Impact refers to the level of confidence that the completed work will affect the company's goals.

Organisational Commitment (Z)

The intervening variable in this study is Organisational Commitment; it is the belief and desire of employees to grow, develop with the organisation, and maintain their membership in the organisation. Trimisat (2020) explains that organisational commitment is "a situation where an employee is on the side of a particular organisation and its goals and desires to maintain membership in the organisation. Koesmono (2018) distinguishes organisational commitment into three forms, i.e., affective component, normative component, continuance commitment, and economic value.

Organisational Citizenship Behavior $(Y)$

Organisational Citizenship Behavior (OCB) is a distinctive type of work behavior where individual actions may benefit the organisation and inexplicitly recognized by formal reward systems. OCB may have a significant impact on the effectiveness and efficiency of the team and organisational work. Thus, the contribution spreads to overall organisational productivity. Organ et al. (2006) define OCB as the behavior of a person who has the freedom to choose that is not solely due to the official wage system. It aims to improve the effective functioning of the organisation. To clarify OCB behavior, Organ (2006) divides it into five main dimensions namely Altruism, Conscientiousness, Sportsmanship, Courtesy, Civic Virtue.

The data collection method used a questionnaire by distributing an instrument containing a list of questions to the respondent. The closed questionnaire used in order to make the respondents only choose the answer that is considered the most appropriate. Respondents' answers were measured 
using an ordinal scale using a modified Likert scale. The research instrument was tested by using validity and reliability tests.

\subsection{Data Analysis Technique}

The techniques used for data analysis are descriptive and inferential analysis. Meanwhile, model testing was carried out by using Partial Least Square (PLS) analysis. Hypothesis testing using path analysis, $r$ test, and t-test.

\section{EMPIRICAL RESULTS AND DISCUSSION}

The population in this study were 102 employees of Hartono Electronics Malang. The 102 questionnaires distributed to all employees; however, the returned ones were 98 questionnaires, and nine questionnaires were blank. Therefore, the number of questionnaires can be tested was 89 .

\section{TABLE 1. PATH COEFFICIENT}

\begin{tabular}{|l|l|l|l|l|l|}
\hline & $\begin{array}{l}\text { Original } \\
\text { Sample }\end{array}$ & $\begin{array}{l}\text { Sample } \\
\text { Mean }\end{array}$ & $\begin{array}{l}\text { Standard } \\
\text { Deviation }\end{array}$ & $\begin{array}{l}\mathbf{T} \\
\text { Statistics }\end{array}$ & $\begin{array}{l}\mathbf{P} \\
\text { Values }\end{array}$ \\
\hline OC -> OCB & 0.448 & 0.440 & 0.094 & 4.776 & 0.000 \\
\hline PE $>$ OC & 0.492 & 0.492 & 0.085 & 5.778 & 0.000 \\
\hline PE -> OCB & 0.399 & 0.408 & 0.097 & 4.093 & 0.000 \\
\hline
\end{tabular}

Source: Research findings, processed by Smart PLS 3.0, 2020

Based on table 1, all variables are positively related to each other, which mean all independent variables significantly influence the dependent variable. The Organisational Commitment and Psychological Empowerment have positively effect on Organisational Citizenship Behavior.

\subsection{Hypothesis Testing}

4.1.1. Hypothesis Testing H1 (The influence of Psychological Empowerment to Organisational Commitment)

Table 1 presents the original sample value of 0.492 with significance (Sig P 0.000 ) below $5 \%$. The $t-$ statistic is 5.778 , higher than the t-table 1.986 . The original positive sample indicates that psychological empowerment has a positive effect on Organisational Commitment. Based on the result, hence the first hypothesis is accepted.

4.1.2 Hypothesis Testing H2 (The influence of Psychological Empowerment to Organisational Citizenship Behavior) 
The second test aims to test whether Psychological empowerment has a positive effect on Organisational Citizenship Behavior. The original sample value is 0.399 with significance (SigP 0.000) below $5 \%$. The t-statistic is 4.093 , higher than the t-table value of 1.986 . The original positive sample indicates that psychological empowerment has a positive effect on Organisational Citizenship Behavior. Therfore, the second hypothesis is accepted.

\subsubsection{Hypothesis Testing H3 (The Influence of Organisational Commitment to Organisational} Citizenship Behavior)

In the third test, whether Organisational Commitment has a significant effect on Organisational Citizenship Behavior is assessed. Viewed from the original sample is 0.448 with a significance (SigP 0.000 ) below $5 \%$, the t-statistic is 4.776 , higher than the t-table value of 1.986 . Then, the positive original sample value indicates that Organisational Commitment has a positive effect on Organisational Citizenship Behavior. Along with that, the third hypothesis is accepted.

\subsubsection{Hypothesis Testing H4 (The Influence Psychological Empowerment to Organisational Citizenship Behaviour through Organisational Commitment)}

The relationship between the independent variable towards the dependent variable is seen through the mediating variable. The result is presented in Table 2 .

TABLE 2. INDIRECT EFFECT

\begin{tabular}{|c|c|c|c|c|c|}
\hline & $\begin{array}{l}\text { Original } \\
\text { Sample }\end{array}$ & $\begin{array}{l}\text { Sample } \\
\text { Mean }\end{array}$ & $\begin{array}{l}\text { Standard } \\
\text { Deviasi }\end{array}$ & $\begin{array}{l}\mathrm{T} \\
\text { Statistics }\end{array}$ & \begin{tabular}{|l}
$P$ \\
Values
\end{tabular} \\
\hline PE-> OC-> OCB & 0.221 & 0.217 & 0.061 & 3.598 & 0.000 \\
\hline
\end{tabular}

Source: Research finding, processed by Smart PLS 3.0, 2020

Based on Table 2 the indirect effect of Psychological Empowerment on Organisational Citizenship Behavior has a significant value. It is seen in the value of $t$ statistics $3.598>1.96$ and $p$-value 0.000 $<0.05$. This can be concluded that Organisational Commitment has an effect of full mediation or partial mediation to the Psychological Empowerment on Organisational Citizenship Behavior. From the test, it appears that when the influence of the mediator is put in the model, it shows that psychological empowerment has a significant influence on Organisational Citizenship Behavior. which is indicated by the original sample value of 0.221 with a significant level at 0.000 smaller $(<)$ than 0.05 so that it infers that Organisational Commitment could intervene the effect of Psychological empowerment on Organisational Citizenship Behaviour. To sum up, the fourth hypothesis is accepted 


\subsection{Discussion}

\subsubsection{The Influence of Psychological empowerment to Organisational Commitment}

The results of this study indicate that psychological empowerment has a positive and significant effect on Organisational Commitment. This result shows that the better employee empowerment, the better employee commitment to the company. Psychological empowerment is measured using four dimensions, i.e., meaningfulness, competence, self-determination, and impact. Those are in line with the result of questionnaires where $64.31 \%$ of the employees agreed that employees like work activities; able to complete the job given well; have mastered the field of work; feel that there is involvement in work because the boss asks the respondent's opinion in making decisions related to his job.

The results of measurements using the Partial Least Square (PLS) analysis tool show that the four valid dimensions reflect psychological empowerment. In addition, the dimension that is conceptually considered important is self-determination (PE 6) with the highest factor loading value (0.882), which is presented in table 3.

TABLE 3. OUTER LOADINGS

\begin{tabular}{|l|l|l|}
\hline Variable & Indicator & Outer Model \\
\hline \multirow{4}{*}{$\begin{array}{l}\text { Psychological } \\
\text { empowerment }\end{array}$} & PE1 & 0,770 \\
\cline { 2 - 3 } & PE2 & 0,786 \\
\cline { 2 - 3 } & PE3 & 0,746 \\
\cline { 2 - 3 } & PE4 & 0,710 \\
\cline { 2 - 3 } & PE5 & 0,763 \\
\cline { 2 - 3 } & PE6 & 0,822 \\
\cline { 2 - 3 } & PE7 & 0,793 \\
\cline { 2 - 3 } & PE8 & 0,747 \\
\hline
\end{tabular}

Source: Research finding, processed by Smart PLS 3.0, 2020

Based on the employee perceptions of the psychological empowerment variable, these results indicate that both conceptually and employees' perceptions of the psychological empowerment variable demonstrate that employees have high confidence about their ability to do work effectively. Therefore, giving trainings and opportunity to participate in planning their targets also can make them loyal and high commitment to achieve company's goal. The results of this study are following the theory asserted by Moye \& Henkin (2006) that employee empowerment is significant because it is a method that can increase the ability to make decisions independently of employees. Employee empowerment can support or provide strength for employees. This research is consistent with ones written by Yani et.al 
(2016) that psychological empowerment has a significant positive effect on organisational commitment. Organisational commitment uses three measurement dimensions, e.g., affective, continuance, and normative commitment. Overall, the three dimensions have validly reflected the organisational commitment variable. The results of measurements using Partial Least Square (PLS) analysis show that continuance commitment (OC 3 ) has the highest loading factor $(0.890)$ shown in Table 4. Continuance commitment is a cost and benefit consideration in the employee, related to the desire to keep working or leave the organisation. Continuance commitment is the commitment when employees stay in the organisation because they need to do it, and there is no other choice (Allen and Meyer, 2013). Employees who work on this continuance commitment stay in the organisation because employees need to do so in the absence of other options.

TABLE 4. OUTER LOADINGS

\begin{tabular}{|l|l|l|}
\hline Variable & Indicator & Outer Model \\
\hline \multirow{5}{*}{ Organisational Commitment } & OC1 & 0,859 \\
\cline { 2 - 3 } & OC2 & 0,854 \\
\cline { 2 - 3 } & OC3 & 0,890 \\
\cline { 2 - 3 } & OC4 & 0,854 \\
\cline { 2 - 3 } & OC5 & 0,857 \\
\cline { 2 - 3 } & OC6 & 0,788 \\
\hline
\end{tabular}

Source: Research findings, processed by Smart PLS 3.0, 2020

Based on the analysis results, it infers that conceptually employees consider that continuous commitment is crucial. Affective commitment is related to employee emotional attachment, employee identification, and employee involvement in the organisation. It means that employees who have a strong affective commitment will continue to work in the organisation because they want to do this, not because of the force or there is no other alternative. Supported by the result of questionnaires which also prove that $54.1 \%$ employees agreed that they were willing to give their best beyond what was expected; proud to be part of the company where they work today, always trying to achieve the best job performance; happy to work in the company.

\subsubsection{The Influence of Psychological Empowerment on Organisational Citizenship Behavior}

The results of this study demonstrated that psychological empowerment has a positive-significant effect on Organisational Citizenship Behavior. This result means that the better the employee empowerment, the better the Organisational Citizenship Behavior. It shows that employees who have a high mean score of psychological empowerments will desire to carry out Organisational Citizenship Behavior. 
Psychological empowerment reflects the attitude of employees who state that the current field of work of employees is meaningful for employees and employees feel love and can master their area of work, and employees can complete the task given by good. This exhibited that psychological empowerment can be a source of motivation for employees to take OCB actions. When employees show more OCB in their works, such as helping co-workers voluntarily; willing to do the duty of absence co-workers without being asked; always arrive at the office on time and has a tolerance if there are policy changes within the company, as well as are willing to advise employee co-workers if they have problems at work. This kinds of proven that psychological empowerment is a factor that influences actions to perform OCB.

This is in line with Podsakof and MacKenzie (2006) who attested that employees who have the freedom to determine how they behave, and complete the work are related to the forming aspects of Organisational Citizenship Behavior, namely conscientiousness. This behaviour shown by trying to exceed what is expected by the company. The results are under Putra (2017) research asserted that psychological empowerment is a source of internal employee motivation, which can increase one's motivation and stimulate a more active OCB. Corroborating with previous research, Tabasi and Gorji (2016), Seibert et al. (2011) deduced that Psychological Empowerment influence Organisational Citizenship Behavior.

\subsubsection{The Influence of Organisational Commitment to Organisational Citizenship Behaviour}

The results of this research indicate that there is an Organisational Commitment that has a positivesignificant effect on Organisational Citizenship Behaviour. It explains that employees who have high organisational commitment will influence employees to do Organisational Citizenship Behaviour. The results of measurements using the Partial Least Square (PLS) analysis tool show that the three indicators are valid, i.e., indicators of affective commitment, normative commitment, and sustainable commitment. Meanwhile, the indicator conceptually considered important is the normative commitment (OCB 1) with the highest factor loading value (0.839) shown in table 5 .

It demonstrates that employees are willing to voluntarily help work colleagues who are overloaded. In addition, employees also feel proud to be part of the company where the employee works. For an employee, OCB is a form of commitment to the organisation. Someone who has a high commitment will always carry out positive behavior to show loyalty, although the tasks are outside the job description given by the organisation. 
TABLE 5. OUTER LOADINGS

\begin{tabular}{|l|c|c|}
\hline Variable & Indicators & Outer Model \\
\hline \multirow{4}{*}{ Organizational } & OCB1 & 0,839 \\
\cline { 2 - 3 } Citizenship Behavior & OCB2 & 0,778 \\
\cline { 2 - 3 } & OCB3 & 0,801 \\
\cline { 2 - 3 } & OCB4 & 0,772 \\
\cline { 2 - 3 } & OCB5 & 0,788 \\
\cline { 2 - 3 } & OCB6 & 0,731 \\
\cline { 2 - 3 } & OCB7 & 0,706 \\
\cline { 2 - 3 } & OCB8 & 0,710 \\
\cline { 2 - 3 } & OCB9 & 0,735 \\
\cline { 2 - 3 } & OCB10 & 0,789 \\
\hline
\end{tabular}

Source: Processed data, 2021

Organisational commitment is the identification and involvement of someone who is relatively firm in their organisation. Organisational commitment is the desire of organisational members to maintain membership in the organisation and is willing to make high efforts for achieving organisational goals. Employee commitment to the organisation occurred in Hartono Electronics Malang is excellent, as evidenced by the grand mean value obtained for the variable organisational commitment of 3.85 . The employees' commitment at Hartono Electronics Malang was measured by three indicators, i.e., affective, normative, and sustainable commitment showing excellent results. Based on the research results, employees have a strong affective commitment, such as happy to work in the workplace, and also employees feel that organisational problems are also employee problems. Employees have a normative commitment, such as feeling heavy to leave the organisation and feeling proud to be a part of the organisation. Employees also have an ongoing commitment, such as the willingness to work hard for the progress of the organisation and care about the future that will happen to the organisation. Organisational commitment causes increased engagement between employees and the organisation, which is corroborate with the result of Kariuki and Kiambati (2017); Lavelle et al. (2009).

This will increase the commitment of each individual in the organisation because commitment can urge employees more loyal to work in the organisation. Based on the path test, it shows the path coefficient value of 0.448 and it interprets that the organisational commitment of employees of Hartono Electronics Malang has a positive influence of $44.8 \%$ on organisational citizenship behaviour. The conclusion is organisational commitment has a significant effect on organisational citizenship behaviour, where the higher the employee's commitment to the organisation, the higher the organisational citizenship behaviour will be. This is following the theory put forward by Robbins and Judge (2015), which states that Organisational Citizenship Behavior can arise from various factors in the organisation, including due to high organisational commitment from employees. The results of this research support the research of Prameswari \& Suwandana (2017), that the factors encouraging the existence of 
Organisational Citizenship Behavior of employees are the result of the influence of several motives, i.e., commitment to the organisation where there is a desire to participate well in the organisation and are proud to be part of the organisation.

\subsubsection{The Influence of Psychological Empowerment on Organisational Citizenship Behaviour through Organisational Commitment.}

The results indicate that Organisational Commitment can be the intervening variable in the influence of Psychological Empowerment on Organisational Citizenship Behaviour. Table 2 shows the indirect effect of Psychological empowerment on Organisational Citizenship Behavior has a significant value, from the value of $t$ statistics $3.598>1.96$ and $p$-value $0.000<0.05$. This explains that high organisational citizenship behaviors are the act when the employees willing to do the duty of absence co-workers, help co-workers who are being chased by deadlines, want to come to the office at an earlier time, willing to complete their work faster than the set time, and willing to do additional works without expecting anything in return. Meanwhile, employees with high psychological empowerment tended to have a big responsibility for their work, such as arriving on time or even earlier than the stipulated time, low absenteeism, and willing to help other employees who experience difficulties. This results consistent with Tabasi and Gorji (2016), Kariuki and Kiambati (2017); Lavelle et al (2009). who generate a conclusion that organisation behaviour can mediate the correlation between Psychological Empowerment to Organisational Citizenship Behavior. Employees who have a high sense of organisational citizenship behavior will have an impact on the progress of the company. Organisational citizenship behavior can increase the productivity of workers with mutual help behavior between colleagues to accelerate task completion; increase manager productivity, namely by providing suggestions and feedback to employees for the progress of work units and avoiding conflicts with 
Organisational Commitment of the staff, as well as servicing a good organisation environment in order to enhance job satisfaction and supported by excellent leadership behaviour.

\section{CONCLUSIONS}

To sum up inferred are Hypothesis 1 is accepted, means Psychological Empowerment has a positive and significant effect on the Organisational Commitment of employees at Hartono Electronics Malang. Hypothesis 2 is accepted, which conclude that Psychological empowerment has a positive and significant effect on the Organisational Citizenship Behavior. The third hypothesis 3 that presumed Organisational Commitment has a positive and significant effect on the Organisational Citizenship Behavior is accepted. The hypothesis 4 is accepted, which infers that Organisational Commitment can be an intervening variable on the influence of Psychological Empowerment on Organisational Citizenship Behavior at Hartono Electronics Malang's employees.

\section{SUGGESTIONS}

Some suggestions are put forward in the research as follows:

The management of Hartono Electronics Malang needs to make efforts to improve organisational citizenship behaviour (OCB) for employees so that they can carry out additional tasks by providing a good work environment, appropriate wage standards, and fairness in giving jobs so that employees will want to complete tasks outside its formal duties and can contribute to the achievement of the goals set by the company.

The management of Hartono Electronics Malang should build a good relationship between managers and employees. The company needs this because leaders are pattern that will later be used as guidance for their employees. Besides, a good relationship between leaders and employees is necessary to create an atmosphere of work and a good work environment.

Further research is expected to expand the scope of research, namely industrial and service companies to be able to see the differences in characteristics resulting from employee characteristics. Then, further research can further explore the factors that influence employees to demonstrate organisational citizenship behaviour such as personal organisation fit, perceived organisational support, personality, and others.

\section{REFERENCES}

Afin Murtie. (2012). Menciptakan Sumber Daya Manusia yang Handal dengan Training, Coaching \& Motivation. Gelora Aksara Pratama. 
Agung Prihantoro. (2012). Peningkatan Kinerja Sumber Daya Manusia melalui Motivasi, Disiplin, Lingkungan Kerja, dan Komitmen. STIE Agama Islam Mathali'ul Falah.

Allen and Meyer. (2013). The Measurement and Antecedents of Affective, Contintinuance and NormativeCommitment to Organitazion. PT Elex Media Komputindo, Jakarta.

Bhatnagar, J., \& Sandhu, S. (2005). Psychological Empowerment and Organisational Citizenship Behavior in IT Managers: A Talent Retention Tool. Indian Journal of Industrial Relations. Indian Journal of Industrial Relations, 40(4), 449-469.

Eisenberger, R., Armelia, S., Rexwinkel, B., Lynch, P.D., \& Rhoades, L. (2001). Reciprocation of Perceived Organizational Support. Journal of Applied Psychology, 86, 42-51.

Janssen, O. (2004). The barrier effect of conflict with superiors in the relationship between employee empowerment and organisational commitment. Work \& Stress. 18(1), 56-65. https://doi.org/10.1080/02678370410001690466

Joo, B.-K., \& Shim, J. H. (2010). Psychological empowerment and organizational commitment: the moderating effect of organizational learning culture. Human Resource Development International, 13(4), 425-441.

Kariuki, A., \& Kiambati, K. (2017). Empowerment, Organisational Commitment, Organisation Citizenship Behavior and Firm Performance Management Studies. 5(4), 290-300.

Kashif, M., Khan, Y., \& Rafi, M. (2011). An Exploration of the Determinants of OCB in the Telecommunication Sector of Pakistan. Asian Journal of Business Management.

Koesmono, T. (2018). Analysis of the Effect of Organizational Support, Organizational Culture, Stress and Work Motivation on Work Satisfaction and Organizational Commitment, Effect of Work Satisfaction on Organizational Commitment with Moderation Variables Leadership in Priva. Journal of Economics and Sustainable Development, 9(22), 144-156.

Kreitner, R. \& Kinichi, A. (2005). Organizational Behavior. Richard D. Irwin, Inc.

Lavelle, J. J., Brockner, J., Konovsky, M. A., Price, K. H., Henley, A. B., Taneja, A., \& Vinekar, V. (2009). Commitment, procedural fairness, and organisational citizenship behavior: a multifoci analysis. Journal of Organisational Behavior, 30(3), 337-357.

Luthans Fred. (2011). Organizational Behavior. McGraw-Hill Company.

M, G. (2013). Relationship between psychological empowerment of employees and organisational citizenship behavior. Australian Journal of Basic and Applied Sciences, 7(1), 67-75.

Mangundjaya, W. H., \& Ratnaningsih, I. Z. (2017). Gaya Kepemimpinan Transformasional, Jenis Generasi, Dan Psychological Empowerment Pada Karyawan PT. X Karawang. Empati, 6(1), 436441.

Moye \& Henkin. (2006). Exploring associations between employee empowerment and interpersonal trust in managers. Journal of Management Development, 25, 101-117.

Organ, D.W., Podsakoff, P.M., Mackenzie, S. B. (2006). Organizational Citizenship Behavior: Its Nature, Antecedents Consequences. Sage Publication Ltd.

Potgieter, M., Bester, J., Kell, D. B., \& Pretorius, E. (2015). The dormant blood microbiome in chronic, inflammatory diseases. FEMS Microbiology Reviews, 39(4), 567-591.

Pradiptya, A. R. (2013). Pengaruh Kepuasan Kerja terhadap Organizational Citizenship Behavior dengan Mediasi Komitmen Organisasional. IImu Manajemen.

Prameswari, K. S., \& Suwandana, G. M. (2017). Pengaruh Keadilan Organisasional, Komitmen Organisasional, Dan Kepuasan Kerja Terhadap Organizational Citizenship Behavior. E-Jurnal 
Manajemen Universitas Udayana, 6(3).

Putra, D. P. (2017). Pengaruh kepuasan kerja, motivasi kerja, dan kepemimpinan terhadap Organizational citizenship behavior dan kinerja karyawan PT. MSH Niaga Telecom Surabaya. Institut Teknologi Sepuluh Nopember.

Putri, P. A., \& Ratnaningsih, I. Z. (2018). Hubungan Antara Psychological Empowerment Dengan Perilaku Kewargaan Organisasi Pada Karyawan Perusahaan Distributor PT. X. Empati, 7(1), 352 361.

Rebentrost, P., Mohseni, M., \& Lloyd, S. (2014). Quantum support vector machine for big data classification. Physical Review Letters, 113(13), 130-503.

Robbin \& Judge. (2015). Perilaku Organisasi Edisi 16. In Salemba Empat.

Seibert, S. E., Wang, G., \& Courtright, S. H. (2011). Antecedents and Consequences of Psychological and Team Empowerment in Organisations. A Meta-Analytic Review. Journal of Applied Psychology, 95(5), 981-1003.

Spreitzer, G. M. (2008). Taking stock: A review of more than twenty years of research on empowerment at work. Handbook of Organizational Behavior, 1, 54-72.

Sugiyono. (2011). Metode Penelitian Kuantitatif, Kualitatif dan R\&D. Afabeta.

Suriadnyana, I. G. (2020). The Effect of Employee Empowerment and Work Stress on Employee Organisational Commitment Mediated by Job Satisfaction (Case Study of Financial Services Cooperatives in Denpasar). Jurnal Ekonomi Dan Bisnis Jagaditha, 7(2), 92-103.

Tabasi, F., \& Gorji, M. B. (2016). To Study the Mediating Role of Organizational Commitment on Empowerment of Employees and Social Capital in Golestan Province Red Crescent Society. International Research Journal of Management Sciences, 4(5), 332-337.

Taştan, S. B., \& Serinkan, C. (2013). An Empirical Research On The Relationship Between Individuals' Psychological Empowerment And Voluntary Performance Behaviors: An Assessment Of The Combination Of Pyschological Power And Intimate Will. Journal of Global Strategic Management, 13, 100-124.

Triatmanto, B., Hariyono, T. A., \& Sanusi, A. (2017). The effect of transformational leadership, organizational commitment and empowerment on managerial performance through organizational citizenship behavior at PT. Cobra Direct Sale Indonesia. International Journal of Business and Management Invention, 6(6), 23-31.

Trimisat, M. I. (2020). Pengaruh Keadilan Organisasional, Kepuasan Kerja, Dan Komitmen Organisasional Terhadap Organizational Citizenship Behavior (Ocb)(Studi Kasus Pada Pegawai Kantor Pelayanan Pajak Pratama Purworejo). Volatilitas, 2(1).

Wadhwa, D. S., \& Verghese, M. (2015). Impact of Employee Empowerment on Job Satisfaction and Organizational Commitment: An Empirical Investigation with Special Reference to Selected Cement Industry in Chhattisgarh. International Journal in Management and Social Science, 3(3), 280-286.

Wibisono, J. F., \& Widjaja, D. C. (2014). Analisa Pengaruh Employee Empowerment Terhadap Service Quality Di Japanese Restaurant. Jurnal Hospitality Dan Manajemen Jasa, 2(2), 292-311.

Yani, A. N. R., Susilo, H., \& Ruhana, I. (2016). Pengaruh Penempatan Karyawan Terhadap Motivasi dan Kinerja. Administrasi Bisnis. 